\title{
ANALISIS KELAYAKAN USAHATANI TOMAT (Lycopersicum esculentum Mill) (Studi Kasus di Desa Cibeureum Kecamatan Sukamantri Kabupaten Ciamis)
}

\author{
ACEP AGUNG GUMELAR ${ }^{*}$, IWAN SETIAWAN ${ }^{2}$, AGUS YUNIAWAN ISYANTO ${ }^{1}$ \\ ${ }^{1}$ Fakultas Pertanian, Universitas Galuh \\ ${ }^{2}$ Fakultas Pertanian, Universitas Padjadjaran \\ *Email: cepagung30@gmail.com
}

\begin{abstract}
ABSTRAK
Hasil penelitian menunjukkan Besarnya biaya total pada usahatani tomat $\mathrm{Rp} 32.085 .284,054$. Sedangkan penerimaannya adalah Rp 75.987.654,32, diperoleh dari hasil panen tomat 30.395,06 kilogram per hektar dengan harga Rp 2.500/kg dan memperoleh pendapatan Rp 43.902.370,28 per hektar per satu kali musim tanam. Besarnya R/C pada usahatani tomat di Desa Cibeureum Kecamatan Sukamantri Kabupaten Ciamis adalah 2,37. Setiap pengeluaran biasa Rp 1,00 maka petani tomat akan mendapat penerimaan $\mathrm{Rp} 2,37$ sehingga petani tomat memperoleh keuntungan Rp 1,37.
\end{abstract}

Kata Kunci : Usahatani, Tomat

\section{ABSTRACT}

Thus the use of the entire population without having to draw the research sample as a unit of observation is called a census technique. The results showed that the total cost of tomato farming in Cibeureum Village, Sukamantri District, Ciamis Regency, Rp. 32,085,284,054 per hectare per one planting season. Meanwhile, the revenue is IDR 75,987,654.32 per hectare per planting season, obtained from the tomato harvest of 30,395.06 kilograms per hectare at a price of IDR 2,500/ $\mathrm{kg}$ and earns IDR 43,902,370.28 per hectare per one planting season. . The amount of $R / C$ in tomato farming in Cibeureum Village, Sukamantri District, Ciamis Regency is 2.37. For every ordinary expenditure of $R p .1 .00$, the tomato farmer will receive $R p .2 .37$, so the tomato farmer will get $R p$. 1.37. Thus, the tomato farming in Cibeureum Village, Sukamantri District, Ciamis Regency is feasible to be cultivated.

\section{PENDAHULUAN}

\section{Latar Belakang}

Kesadaran masyarakat akan pentingnya mengonsumsi sayuran mendorong petani untuk membudidayakan sayuran sehingga produksi sayuran petani diharapkan dapat mencukupi kebutuhan masyarakat dan memberikan keuntungan kepada petani sebagai produsen (Kinanti, 2018). Salah satu cara untuk mengetahui kelayakan usaha diantaranya dengan menggunakan analisis R/C (Suratiyah, 2006).
$\mathrm{R} / \mathrm{C}$ adalah perbandingan antara penerimaan dengan biaya produksi. Untuk mengetahui kelayakan usahatani tomat harus dilakukan perhitungan secara rinci tentang usahatani tomat ini. Namun permasalahan yang timbul adalah petani tomat di Desa Cibeureum umumnya belum secara rinci melakukan analisis usahataninya.

Hal tersebut perlu dilakukan oleh setiap petani, mengingat pentingnya pencapaian tujuan peningkatan pendapatan dan dalam mengalokasikan sumber daya 
yang ada secara efektif dan efisien. Maka dari itu, penulis tertarik untuk melaksanakan penelitian mengenai Analisis Kelayakan Usahatani Tomat di Desa Cibeureum Kecamatan Sukamantri Kabupaten Ciamis.

Tujuan Penelitian Penelitian ini bertujuan untuk mengetahui :

1. Besarnya biaya, penerimaan dan pendapatan usahatani tomat.

2. Besarnya nilai $\mathrm{R} / \mathrm{C}$ usahatani tomat di Desa Cibeureum Kecamatan Sukamantri Kabupaten Ciamis.

\section{METODE PENELITIAN}

\section{Jenis Penelitian}

Penelitian ini dilaksanakan menggunakan studi kasus pada petani tomat di Desa Cibeureum Kecamatan Sukmantri Kabupaten Ciamis. Menurut Daniel (2007), metode studi kasus lebih mirip dengan metode survei. Bedanya dalam studi kasus, populasi yang diteliti lebih terarah dan terfokus pada sifat tertentu yang tidak berlaku umum. Biasanya dibatasi oleh kasus, lokasi, tempat serta waktu tertentu.

\section{Teknik Penarikan Sampel}

Desa Cibeureum Kecamatan Sukamantri Kabupaten Ciamis ditentukan sebagai lokasi penelitian secara purposive sampling dengan pertimbangan bahwa
Desa Cibeureum merupakan salah satu Desa yang menghasilkan tomat terbanyak di Kecamatan Sukamantri. Pengambilan responden dilakukan secara sampling jenuh atau sensus. Menurut BPP kecamatan sukamantri, bahwa petani yang melakukan usahatani tomat secara berkelanjutan atau continue, sebanyak 15 orang (BPP Kecamatan Sukamantri, 2020). Sehingga menggunakan sampel jenuh. Dengan demikian penggunaan seluruh populasi tanpa harus menarik sampel penelitian sebagai unit observasi disebut sebagai teknik sensus.

\section{Tempat dan Waktu Penelitian}

Penelitian ini dilaksanakan di Desa Cibeureum Kecamatan Sukmantri Kabupaten Ciamis. Adapun waktu penelitian ini dibagi dalam beberapa tahapan sebagai berikut:

1. Survai pendahuluan, penulisan usulan penelitian dan seminar usulan penelitian dilaksanakan pada bulan Februari sampai Maret 2020.

2. Pengumpulan dan pengolahan data dilaksanakan pada bulan April sampai dengan Mei 2020.

3. Pengolahan dan analisis data, serta penulisan Skripsi dilaksanakan pada bulan Juni 2020 sampai dengan selesai selesai.

\section{HASIL DAN PEMBAHASAN}


Analisis Usahatani Tomat a) Analisis Biaya 1) Biaya Tetap Biaya tetap yang dihitung dalam penelitian ini meliputi biaya penyusutan alat, bunga modal $(1,50$ $\%$ per satu kali musim tanam) dan biaya sewa lahan. Besarnya biaya tetap yang dikeluarkan masing-masing Petani berbeda-beda.

Hasil perhitungan rata-rata biaya tetap usahatani tomat seberapa $\mathrm{Rp}$ 4.912.631,33 per hektar per satu kali musim tanam. 2) Biaya Variabel Biaya Variabel yang dihitung dalam penelitian ini meliputi upah tenaga kerja, benih, pupuk organik, NPK, Urea, KCL, SP-36, Insektisida, Fungisida dan Bunga Variabel (1,50\% per satu kali musim tanam).
Hasil perhitungan memperlihatkan bahwa rata-rata besarnya biaya variabel yang dikeluarkan petani tomat $\mathrm{Rp}$ 27.172.652,72 per hektar per satu kali musim tanam. Dalam melakukan kegiatan usahatani tomat membutuhkan tenaga kerja, baik berasal dari tenaga kerja dalam keluarga maupun dari luar keluarga petani tomat. Sistem pembayaran sesuai dengan upah yang berlaku di daerah penelitian yang dibayar secara tunai dengan upah Rp 35.000 sampai Rp 50.000 per orang.

Hasil perhitungan memperlihatkan bahwa rata-rata besarnya biaya total yang dikeluarkan petani tomat di Desa Cibeureum adalah Rp 32.085.284,05 per hektar per satu kali musim tanam.

\section{Tabel 1. Biaya Total Usahatani Tomat per Hektar Satu Kali Musim Tanam}

\begin{tabular}{rr}
\hline \multicolumn{1}{c}{ Komponen Biaya } & Jumlah (Rp) \\
\hline A. Biaya Tetap & $4.011 .635,80$ \\
- $\quad$ Penyusutan Alat & $828.345,06$ \\
- Sewa Lahan & $72.600,47$ \\
- $\quad$ Bunga Modal Tetap & $\mathbf{4 . 9 1 2 . 6 3 1 , 3 3}$ \\
$\quad$ Jumlah & \\
B. Biaya Variabel & $14.736 .518,52$ \\
- Sarana Produksi & $12.034 .567,90$ \\
- Tenaga Kerja & $401.566,30$ \\
- Bunga Modal Variabel & $\mathbf{2 7 . 1 7 2 . 6 5 2 , 7 2}$ \\
\hline Jumlah & $\mathbf{3 2 . 0 8 5 . 2 8 4 , 0 4}$ \\
\hline Total &
\end{tabular}

Analisis Penerimaan dan

Pendapatan Pendapatan merupakan selisih antara penerimaan dengan biaya total yang dikeluarkan, sedangkan penerimaan merupakan hasil perkalian antara harga jual tomat dengan banyaknya produksi tomat yang dihasilkan. Berdasarkan hasil penelitian harga jual tomat pada saat 
penelitian adalah Rp 2.500 per kilogram, sedangkan produksi tomat yang dihasilkan per satu kali musim tanam sebanyak 30.395,06 kilogram per hektar, sehingga didapat penerimaan $\mathrm{Rp} 75.987 .654,32$ per hektar dengan biaya yang dikeluarkan adalah Rp 32.085.284,04 per hektar sehingga diperoleh pendapatan $\mathrm{Rp}$ 43.902.370,28 per hektar per satu kali musim tanam.

$$
\text { R/C R/C (Revenue Cost Ratio) }
$$
diketahui dengan cara pembagian antara penerimaan dengan biaya total. Penerimaan Rp 75.987.654,32 per hektar dan biaya yang dikeluarkan $\mathrm{Rp}$ 32.085.284,054 per hektar. Berdasarkan penelitian diketahui rata-rata $\mathrm{R} / \mathrm{C} \quad 2,37$ artinya setiap pengeluaran biaya $\mathrm{Rp} 1,00$ maka petani tomat akan mendapatkan penerimaan $\operatorname{Rp} 2,37$ sehingga petani tomat memperoleh keuntungan Rp 1,37.

\section{KESIMPULAN}

Kesimpulan Berdasarkan hasil dan pembahasan, maka dapat diambil kesimpulan :

1) Besarnya biaya total pada usahatani tomat di Desa Cibeureum Kecamatan Sukamantri Kabupaten Ciamis Rp 32.085.284,054 per hektar per satu kali musim tanam. Sedangkan penerimaannya adalah $\mathrm{Rp}$ 75.987.654,32 per hektar per satu kali musim tanam, diperoleh dari hasil panen tomat 30.395,06 kilogram per hektar dengan harga Rp 2.500/kg. Besarnya pendapatan pada usahatani tomat di Desa adalah Rp 43.902.370,28 per hektar per satu kali musim tanam.

2) Besarnya R/C pada usahatani tomat di Desa Cibeureum adalah 2,37. Setiap pengeluaran biasa $\mathrm{Rp}$ 1,00 maka petani tomat akan mendapat penerimaan $\mathrm{Rp}$ 2,37 sehingga petani tomat memperoleh keuntungan $\operatorname{Rp} 1,37$.

\section{DAFTAR PUSTAKA}

Arikunto, S. 2006. Prosedur Penelitian, Suatu Pendekatan Praktek. Jakarta : PT. Rineka Cipta.

Cahyono B 2008. Tomat Usahatani dan Penanganan Pascapanen. Yogyakarta.

Badan Penyuluh Pertanian Kecamatan Sukamantri. 2020. Laporan Tahunan 2020. Balai Penyuluh Pertanian Kecamtan Sukamantri Kabupaten Ciamis.

Kinanti. (2018). Analisis Pendapatan Usahatani Sayuran Di Kecamatan Sumberejo Kabupaten Tanggamus. Skripsi. Fakultas Pertanian Universitas Lampung. Bandar Lampung.

Suratiyah, K. 2006. Ilmu usahatani. Penebar Swadaya. Jakarta. 